\title{
Preharvest Application of Hexanal as a Surface Treatment Improved the Storage Life and Quality of Mango Fruits
}

\author{
Palpandian Preethi ${ }^{1, * \mathbb{D}}$, Kadambavanasundaram Soorianathasundaram ${ }^{2}$, Athipathi Sadasakthi ${ }^{3}$, \\ Kizhaeral Sevathapandian Subramanian ${ }^{4}$, Sanikommu Vijay Rakesh Reddy ${ }^{1 \mathbb{D}}$, Gopinadhan Paliyath ${ }^{5} \mathbb{C}$ \\ and Jayasankar Subramanian ${ }^{6}$ \\ 1 ICAR-Indian Institute of Horticultural Research, Bengaluru 560089, India; Rakesh.Reddy@icar.gov.in \\ Department of Fruit Crops, Tamil Nadu Agricultural University, Coimbatore 641003, India; sooria@tnau.ac.in \\ Rice Research Station, Tamil Nadu Agricultural University, Madras 602025, India; sadasakthi@gmail.com \\ Directorate of Research, Tamil Nadu Agricultural University, Coimbatore 641003, India; kss@tnau.ac.in \\ Department of Plant Agriculture, University of Guelph, Guelph, ON N1G 2W1, Canada; gpaliyat@uoguelph.ca \\ 6 Department of Plant Agriculture, Vineland Campus, University of Guelph, Vineland Station, ON L0R 2E0, Canada; \\ jsubrama@uoguelph.ca \\ * Correspondence: pppreethifruitscience@gmail.com; Tel.: +91-9494853060
}

check for updates

Citation: Preethi, P.;

Soorianathasundaram, K.; Sadasakthi, A.; Subramanian, K.S.; Vijay Rakesh

Reddy, S.; Paliyath, G.; Subramanian,

J. Preharvest Application of Hexanal as a Surface Treatment Improved the Storage Life and Quality of Mango Fruits. Coatings 2021, 11, 1267. https://doi.org/10.3390/ coatings11101267

Academic Editor: Jaejoon Han

Received: 3 September 2021

Accepted: 13 October 2021

Published: 19 October 2021

Publisher's Note: MDPI stays neutral with regard to jurisdictional claims in published maps and institutional affiliations.

Copyright: (c) 2021 by the authors. Licensee MDPI, Basel, Switzerland. This article is an open access article distributed under the terms and conditions of the Creative Commons Attribution (CC BY) license (https:/ / creativecommons.org/licenses/by/ $4.0 /)$.

\begin{abstract}
Mango is a highly preferred seasonal tropical fruit with a maximum shelf-life of five to seven days. Hexanal is a plant volatile compound assayed in green tissues and showing significance in enhancing storage life and fruit quality attributes by preserving membrane integrity. This experiment explored the effect of the pre-harvest application of an aqueous hexanal composition (active ingredient: $0.02 \%$ hexanal) in altering the post-harvest storage behavior of four mango cultivars. The pre-harvest application of the hexanal formulation to the fruit surface twice before the harvest date drastically slowed down the physiological loss in weight by $70 \%$ to $80 \%$, and reduced the ethylene evolution rate by two to three folds, respectively. The pre-harvest hexanal formulation spray combined with post-harvest cold storage prominently improved the storage life along with the total soluble solids, total sugars, ascorbic acid and carotenoid content compared to untreated fruits stored in ambient conditions. Though ripening coincides with the increased activity of enzymes, the hexanal formulation spray acts predominantly in bringing down the activities of fruit softening enzymes viz. pectinmethlyesterase (43\%) and polygalacturonases $(37 \%)$, and antioxidant enzymes viz. peroxidase $(67 \%)$ and catalase $(45 \%)$, respectively.
\end{abstract}

Keywords: hexanal; surface coating; mango; membrane integrity; storage life; fruit quality

\section{Introduction}

Mango (Mangifera indica Linn.), the widely acclaimed fruit of India, is known for its delicious taste, excellent flavor and rich nutritional content, especially vitamins A and C. Mango currently ranks fifth in total production among major fruit crops worldwide, with India ranking first in its production. Mango fruits are highly perishable, and are thus susceptible to huge post-harvest losses. Technologies to enhance mango production, postharvest life and market distribution are receiving great attention of late, as there is a huge demand for domestic consumption as well as export trade.

Mango, being characterized with sudden burst of ethylene production, is classified as a climacteric fruit [1]. Most of the climacteric fruits, including mango, are vulnerable to post-harvest losses due to the rapid softening of the peel and pulp tissues, amplified physiological loss in weight, increased susceptibility to pathogens, and damage during transit, etc. Many factors, such as the cultivar, stage of harvest, harvesting methods, grading, handling, packaging and mode of transport affect the storability of mango fruits [2].The internal factors operating on the fruit viz. respiratory processes, ethylene evolution, enzymatic starch hydrolysis, the action of polygalacturonases (PG), pectinmethylesterases (PME) and 
other ripening enzymes leads to the softening of the cell wall, followed by subsequent post-harvest deterioration.

Many new technologies have been developed and standardized for the extension of the shelf life of mango fruits, including the application of generally recommended as safe (GRAS) chemicals, hot water treatment, wax treatment and refrigerated storage [3]. The major storage methods recommended commercially are low temperature storage $\left(13^{\circ} \mathrm{C}\right)$, controlled atmospheric (CA) storage $\left(3-5 \% \mathrm{O}_{2}\right.$ and $\left.5-10 \% \mathrm{CO}_{2}\right)$ and hypobaric storage (76-152 mmHg). Among these technologies, the easily adaptable process for growers and traders is cold storage, which does not involve the maintenance of atmospheric $\mathrm{O}_{2}, \mathrm{CO}_{2}$ or pressure, as are applicable for $\mathrm{CA}$ and hypobaric storage. Fruits stored in modified atmospheres often exhibit undesirable characteristics, such as reduced color development and poor eating quality, with a possible off-flavor production due to $\mathrm{CO}_{2}$ injury [4]. There are several other physiological disorders and pre-harvest factors that impair the quality of harvested mango fruits, although little is known of their development, nature and control. A combination of technologies, such as chemical application coupled with cold storage, has been found to be effective in enhancing the shelf life of fruits like mango.

The pre-harvest application of a hexanal-based composition to the fruit surface has been effective in reducing fruit drop, enhancing retention, increasing shelf life without affecting quality, and reducing the spoilage in various fruits. The formulation contains $0.02 \%$ hexanal, and has been found to enhance the shelf-life of various fruit crops viz. apple, pears, peach, grapes, sweet cherries, strawberry, guava, banana and mango [5-11]. Hexanal, a GRAS chemical of eco-friendly nature, is a six carbon aldehyde produced during the lipoxygenase pathway and released from plants during tissue damage [12,13]. It is an important precursor for the formation of six carbon alcohols and esters, with an imperative role in extending the freshness of fruits and vegetables through the inhibition of the enzyme phospholipase-D (PLD) $[5,6,12]$. Research on hexanal usage in different mango varieties of various locations and its integral effect with cold storagies scanty. Hence, the present study was attempted with four commercial mango cultivars of South India, collected from two locations, to investigate the post-harvest behavioural response of mango fruits to the pre-harvest application of hexanal formulations under ambient and cold storage conditions.

\section{Materials and Methods}

\subsection{Hexanal Formulation Preparation}

The hexanal stock solution for the preharvest spray was prepared using $0.2 \%(v / v)$ hexanal dissolved in an equal volume of Tween 20, the surfactant, and ethanol, the solvent. The spray solution was prepared prior to application, by mixing 1 part stock with 9 parts water $(v / v)$. The hexanal concentration in the final spray solution is $0.02 \%$. The chemicalshexanal (98\% purity) FG, Tween 20 FG, and ethanol-were purchased from Sigma-Aldrich, Bangalore, India.

\subsection{Experimental Plot, Spraying, Harvesting and Transportation}

The experiment was conducted in two major mango growing districts of Tamil Nadu, viz. Krishnagiri (Longitude: $70.50 \mathrm{E}$; Latitude: $12.15 \mathrm{~N}$ ) and Theni (Longitude: $77.20 \mathrm{E}$; Latitude: $9.63 \mathrm{~N}$ ) for three consequent years during the main fruiting seasons (May to July) in four commercial mango cultivars, i.e., Neelum, Bangalora, Banganapalli and Alphonso. Healthy and uniform-sized mango trees of 10 to 15 years old were selected and sprayed with the hexanal formulation at different intervals, viz. once at 15 days before harvest $(15 \mathrm{DBH})$, once at 30 days before harvest $(30 \mathrm{DBH})$, and twice at 15 and 30 days before harvest (15 and30 DBH) with no spray as the control (Control). Approximately $15 \mathrm{~L}$ of hexanal formulation spray fluid was used for the complete drenching of the fruits at the tree crown region.

Physiologically mature fruits were harvested, desapped and wiped with wet tissue to remove the adhering foreign particles. The harvested fruits were transported to the laboratory at Tamil Nadu Agricultural University, Coimbatore in refrigerated wagons at $13 \pm 2{ }^{\circ} \mathrm{C}$. 
The fruits were divided into two lots and stored in ambient $\left(25 \pm 2{ }^{\circ} \mathrm{C}, 52 \pm 3 \% \mathrm{RH}\right)$ and cold $\left(13{ }^{\circ} \mathrm{C}, 90 \pm 3 \% \mathrm{RH}\right)$ storage conditions for further analysis.

\subsection{Selection of Fruits}

Uniform sized fruits were selected based on weight, volume, length and breadth. The weight was measured using a digital weighing balance (Make: Bench Top; Model: BT-PB-203, West Sussex, United Kingdom); volume was calculated by the water displacement method. A digital vernier caliper (Make: Mitutoyo; Model: 500-197-20, Kawasaki, Japan) was used to measure the fruit length and breadth. The recorded data is represented in Table 1.

Table 1. Average fruit weight, volume and size of the different mango varieties used for the experiment.

\begin{tabular}{ccccc}
\hline Mango Variety & Weight $(\mathrm{g})$ & Volume $(\mathbf{m L})$ & Length $(\mathbf{c m})$ & Circumference $(\mathbf{c m})$ \\
\hline Neelum & $180.54 \pm 7.86$ & $177.11 \pm 6.56$ & $7.25 \pm 0.84$ & $23.80 \pm 1.56$ \\
Bangalora & $320.14 \pm 8.03$ & $315.09 \pm 5.52$ & $14.98 \pm 0.86$ & $27.61 \pm 0.84$ \\
Banganapalli & $285.32 \pm 7.45$ & $278.54 \pm 6.38$ & $12.11 \pm 0.83$ & $32.08 \pm 0.96$ \\
Alphonso & $185.15 \pm 5.77$ & $183.15 \pm 5.18$ & $10.16 \pm 0.92$ & $26.18 \pm 0.88$ \\
\hline
\end{tabular}

Values are the mean \pm standard deviation of 500 fruits of each variety.

\subsection{Postharvest Quality Factors}

The fruits were randomly selected $(n=15)$ and marked from four replications for the recording of the physiological loss in weight (PLW), respiration rate, ethylene production and storage life, and the same fruits were sampled for destructive analytical parameters towards the end for firmness, and biochemical analysis. However, for the enzymatic analysis, a set of separate fruits $(n=15)$ were drawn from the replicated lot for the periodic data.

\subsubsection{Storage Life}

The number of days taken by the fruits to reach the optimal edible ripe stage from the day of harvest was counted and reported in days.

\subsubsection{Firmness}

The firmness of the fruit was measured at three different positions, the proximal, distal and middle portion [14], by measuring the force required to puncture the fruit using a penetrometer (Make: Lutron; Model: FG 5000a, Taipei, Taiwan), and was expressed in Newtons $(\mathrm{N})$.

\subsubsection{Physiological Loss in Weight}

The physiological loss in weight (PLW) was calculated according to the formula mentioned below:

$$
\text { PLW }(\%)=\frac{\text { Initial weight }- \text { Final weight }}{\text { Initial weight }} \times 100
$$

\subsubsection{Respiration Rate and Ethylene Evolution Rate}

The respiration rate of treated and untreated mango fruits of known weight and volume was measured using an auto gas analyzer (Make: PBI Dansensor; Model: checkpoint, $\mathrm{CO}_{2} / \mathrm{O}_{2}$ gas analyser, Ringsted, Denmark). The $\mathrm{CO}_{2}$ evolution was calculated in $\mathrm{mg} / \mathrm{kg} / \mathrm{h}$ by using following formula:

$$
\mathrm{CO}_{2}(\mathrm{mg} / \mathrm{kg} / \mathrm{h})=\frac{2 \times \% \mathrm{CO}_{2} \times(\text { Container volume }- \text { Fruit volume }) \times 60}{\text { Fruit weight }(\mathrm{kg}) \times \text { Enclosing time }(\mathrm{min}) \times 100} .
$$


The ethylene evolution rate was calculated using an ethylene analyzer (Range: 0-100 ppm Ethylene; Resolution: $0.1 \mathrm{ppm}$; Temperature range: $0-35{ }^{\circ} \mathrm{C}$; Pump Flow: Typically $0.8 \mathrm{~L} / \mathrm{min}$; Make: Bioconservacion, Spain) using the following formula:

$$
\mathrm{C}_{2} \mathrm{H}_{4}(\mu \mathrm{L} / \mathrm{kg} / \mathrm{h})=\frac{\mathrm{C}_{2} \mathrm{H}_{4} \mathrm{ppm} \times(\text { Container volume }- \text { Fruit volume }) \times 60}{\text { Fruit weight }(\mathrm{kg}) \times \text { Enclosing time }(\mathrm{min}) \times 1000} .
$$

\subsubsection{Biochemical Parameters}

The total soluble solids (TSS) were determined using a digital refractometer (PAL 3, Atago Ltd., Tokyo, Japan) at $25^{\circ} \mathrm{C}$ temperature and expressed in degree Brix $\left({ }^{\circ} \mathrm{B}\right)$. The total sugars present in the mango fruits were estimated using the Anthrone method [15], and the titration method was used to estimate the ascorbic acid, which was expressed as $\mathrm{mg} / 100 \mathrm{~g}$ of pulp [16]. The total carotenoids in the mango sample extracted using $80 \%$ acetone were measured with a UV-Visible spectrophotometer (Make: Shimadzu UV-1900, Kyoto, Japan) at 480 and $510 \mathrm{~nm}$, calculated using following formula and expressed as $\mathrm{mg} / \mathrm{g}$ of pulp [17].

Total carotenoids $=\frac{(7.6 \times \text { absorbance value at } 480 \mathrm{~nm})-(1.49 \times \text { absorbance value at } 510 \mathrm{~nm}) \times \text { Final vol. of supernatant in } \mathrm{mL}}{1000 \times \text { Weight of mango pulp taken in } \mathrm{g}}$

\subsubsection{Enzyme Activity}

The activity of the fruit-softening and antioxidant enzymes was determined using the standard protocols. Pectinmethylesterase (PME) was determined by the colorimetric method [18]. The anthrone method and standard curve of D-galacturonate were used to estimate the Polygalacturonase (PG) [19]. Peroxidase (POX) was estimated spectrophotometrically [20], and the titration method was used to determine the catalase (CAT) [21]. Hydrogen peroxide was used as a substrate for the determination of the antioxidant enzymes.

The enzyme assays were carried out periodically from the experimental set of fruits at the start of the experiment (0th day) to the 9th day of storage in order to monitor the enzymatic changes. The enzyme activity was recorded as the unit $/ \mathrm{mg}$ protein $/ \mathrm{min}$. The data were represented as the percentage rate of change (\% ROC) between the 0 th and 9 th day of enzyme activity.

\subsection{Statistical Analysis}

In this experiment, the postharvest properties of the mango fruits were ascertained in four replicates carrying 15 fruits each. The overall means obtained from the treatment, location and year were subjected to an analysis of variance (ANOVA) and Fisher's Least Significant Difference at the $5 \%$ level $(p=0.05)$. The data are represented as the mean values \pm standard deviation of four replicates; the letter after the mean value indicates the significance at the $5 \%$ level, in the order $a>b>c>d$. The entire analysis was performed using an online SAS program (version 9.3).

\section{Results}

\subsection{Storage Life}

Using the hexanal formulation on mango fruits' surface was found to have a profound effect in increasing the storage life irrespective of the cultivar, location and season. The mango fruits treated with the hexanal formulation showed annex tended storage life of 15 days in comparis onto the 4 days observed in the control fruits (Figure 1A,B). Among the single (15 DBH, $30 \mathrm{DBH})$ and double applications (15 and $30 \mathrm{DBH})$ of the hexanal formulation, the double application treatment increased the mean storage life to 8 days in ambient storage and 16 days in cold storage against 5 days for ambient stored control fruits. The hexanal formulation had a similar effect on the storage life of all four mango cultivars, with an increase in the average storage period from 5 to 16 days (Figure S1). The cultivar Banganapalli exhibited the highest storage life of 9 days under ambient conditions, which was extended to 19 days with the combined effect of a double application of hexanal formulation (15 and $30 \mathrm{DBH}$ ) and cold storage. 


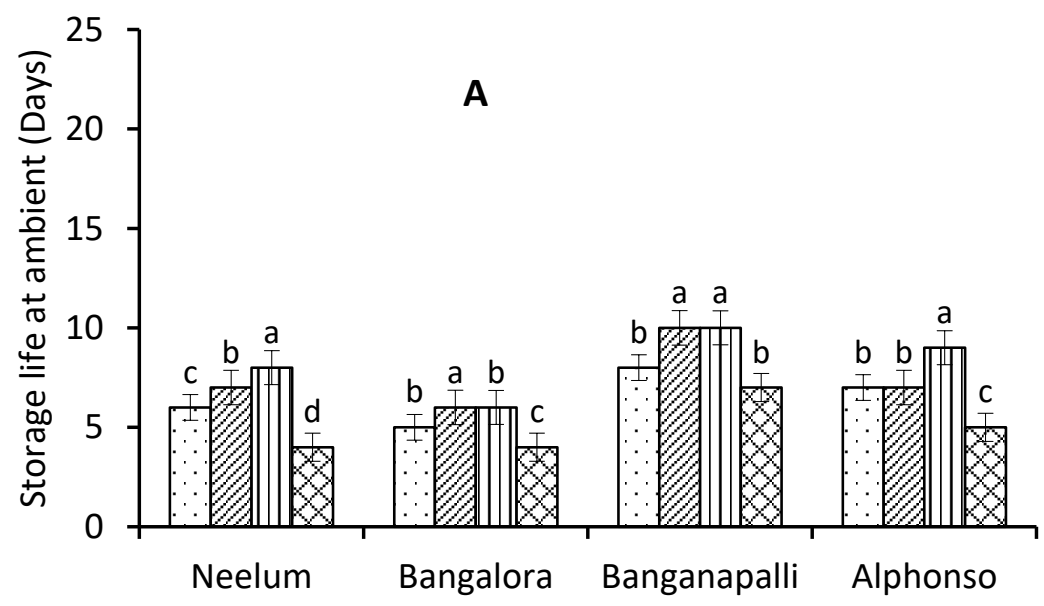

Hexanal spray at $\square 15 \mathrm{DBH} \quad \square 30 \mathrm{DBH} \quad \square 15 \& 30 \mathrm{DBH}$ - $\mathrm{Control}$

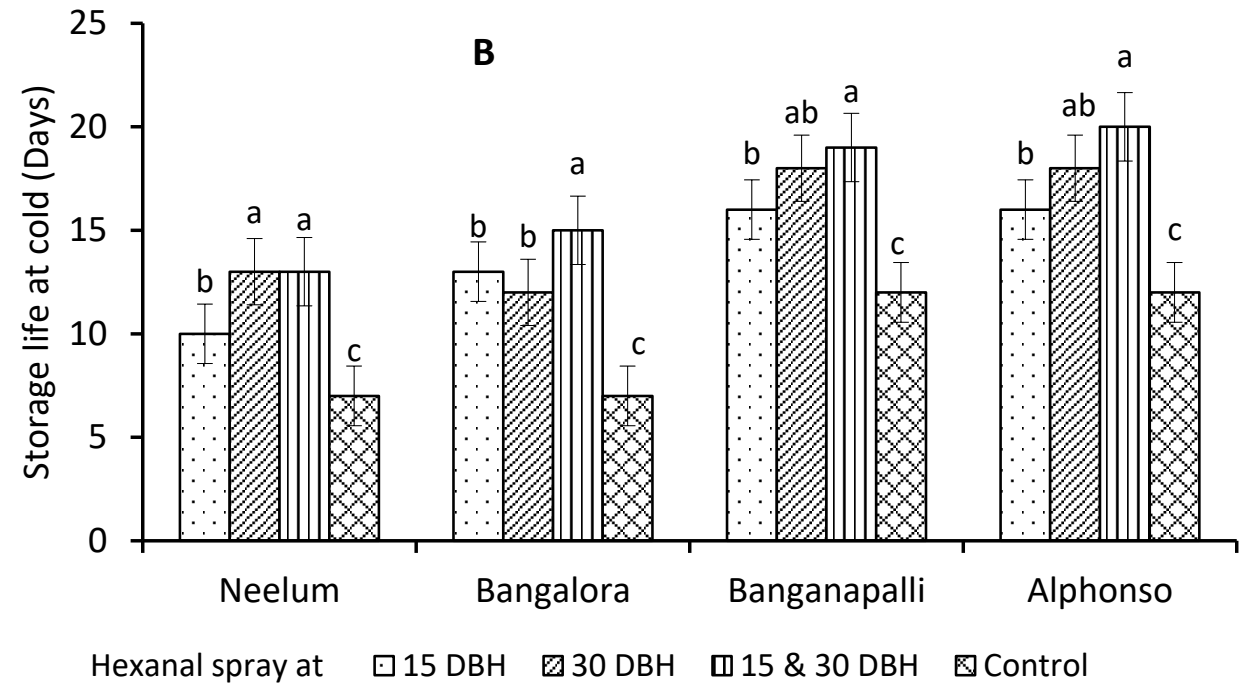

Figure 1. Mean storage life of hexanal-treated and control mango fruits of different cultivars under ambient (A) and cold (B) storage conditions. The vertical bars in the columns represent the standard error of four replicates $(n=15)$. Columns with different and the same letters indicate statistical significance and non-significance, respectively $(p=0.05)$. DBH-Days before harvest.

\subsection{Fruit Firmness}

A Consistent reduction in fruit firmness was observed in general in the ambient and cold storage conditions. A double application of the hexanal formulation on the fruit surface prior to harvest (i.e., 15 and $30 \mathrm{DBH}$ ) significantly retained the fruit firmness in all of the mango cultivars (Figure 2A,B). The average puncture force required for the penetration of the probe into untreated (Control) and single-dose applied mango fruits of the cultivars-namely Neelum, Bangalora, Banganapalli and Alphonso-reduced by 21\%, $22 \%, 28 \%$ and $34 \%$, respectively, against the double-dose applied fruits. The cold stored mango fruits of cvs. Neelum, Bangalora, Banganapalli and Alphonso exhibited increased textural firmness by $56 \%, 63 \%, 71 \%$ and $60 \%$, respectively, compared to the ambient stored double-dose treated fruits. 

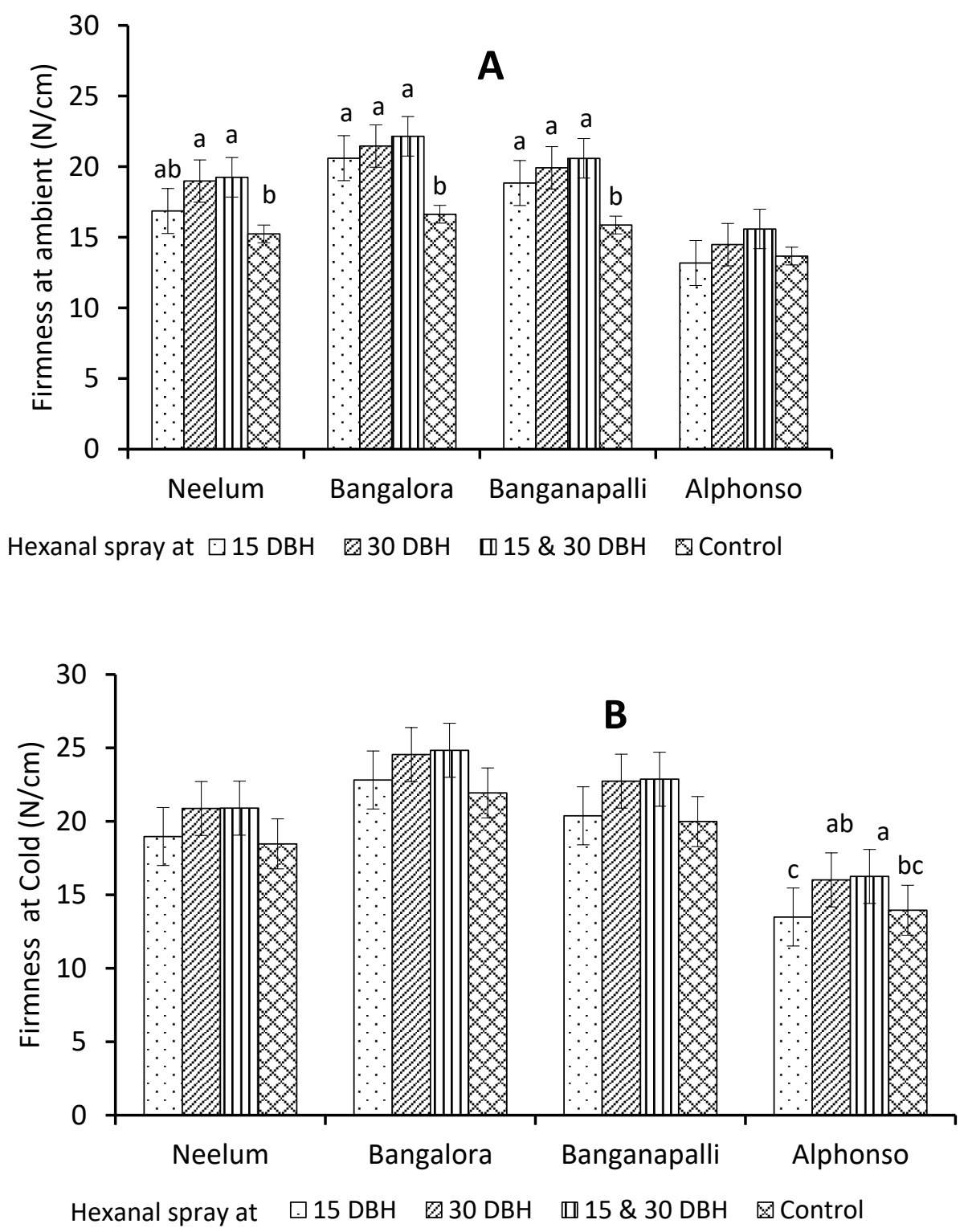

Figure 2. Mean firmness of the hexanal-treated and control mango fruits of four cultivars towards the end of the storage life under ambient $(\mathbf{A})$ and cold $(\mathbf{B})$ storage conditions. Vertical bars in the columns represent the standard error of four replicates $(n=15)$. The columns with and without or same letters indicate statistical significance and non-significance, respectively $(p=0.05)$. DBH-Days before harvest.

\subsection{Physiological Loss in Weight (PLW)}

The pre-harvest application of the hexanal formulation on the fruit surface produced a significant $(p=0.05$ ) reduction in the PLW of mango fruits irrespective of the cultivar and storage temperature (Figure 3A,B). Although, the effects of single and double doses of hexanal formulation were comparable, there was a steep rise in the PLW of ambientstored untreated fruits compared to the double-dose treated fruits stored under cold storage. The integration of double-dose hexanal application with cold storage resulted in a significant reduction of PLW to the extent of $71 \%, 81 \%, 79 \%$ and $70 \%$ in the four cultivars Neelum, Bangalora, Banganapalli and Alphonso, respectively, compared to their respective untreated mango fruits. The overall results indicate that the double-dose application of the hexanal formulation as a pre-harvest spray at 15 and $30 \mathrm{DBH}$ could significantly control the PLW of mango fruits. 

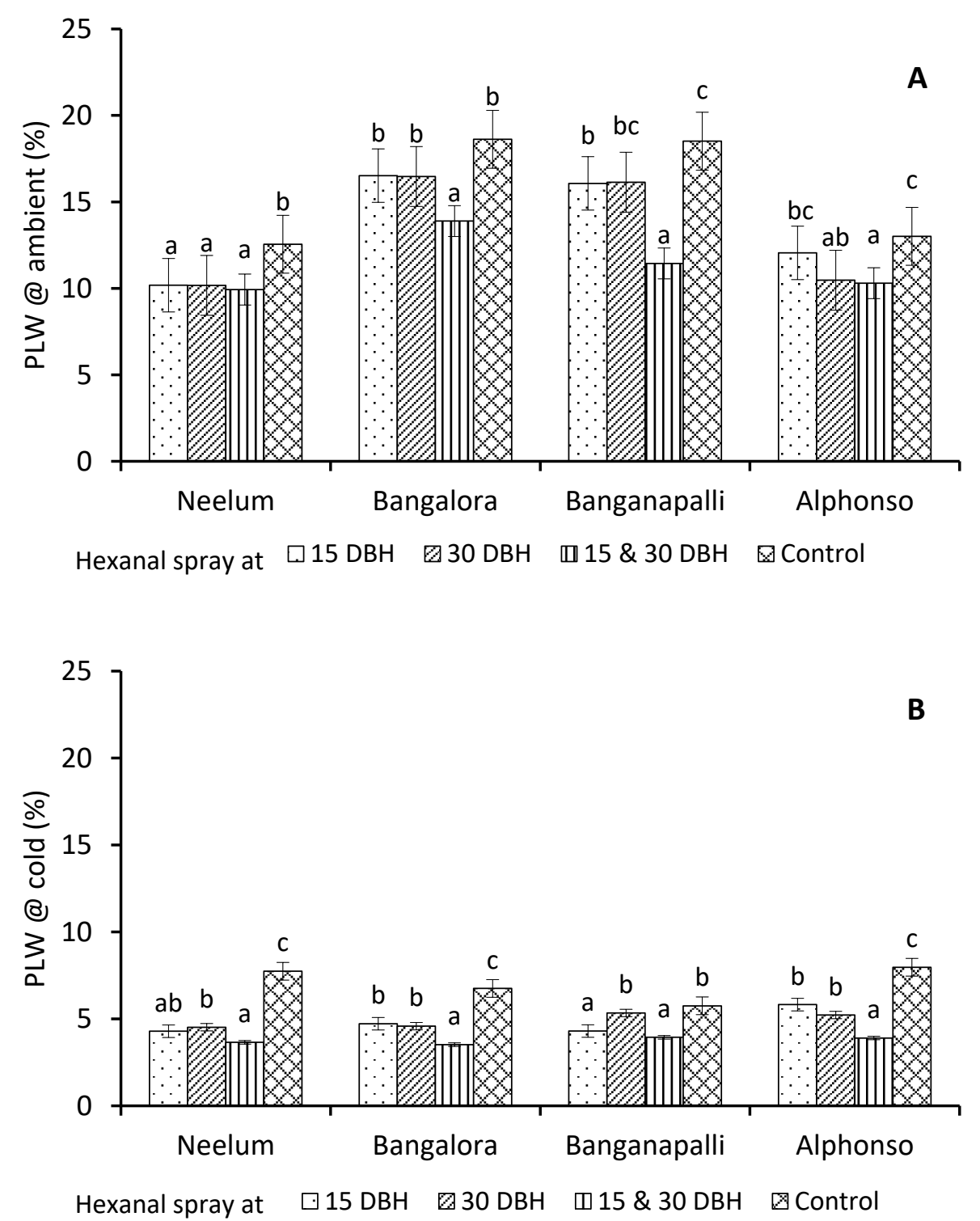

Figure 3. Mean PLW of hexanal-treated and control mango fruits of four cultivars towards the end of their storage life under ambient (A) and cold (B) storage conditions. The vertical bars in the columns represent the standard error of four replicates $(n=15)$. The columns with different and the same letters indicate statistical significance and non-significance respectively $(p=0.05)$. DBH-Days before harvest.

\subsection{Respiration Rate and Ethylene Evolution Rate}

Significant reductions in the respiration rate and ethylene evolution rate of the mango cultivars were recorded in double-dose treated fruits (15 and $30 \mathrm{DBH})$ at ambient as well as cold storage conditions. The average rate of respiration and ethylene evolution of the treated and control fruits showed that the hexanal formulation had a significant effect in reducing the post-harvest respiratory behavior and ethylene evolution rate of the mango fruits (Figure 4A,B). Irrespective of the storage conditions, all of the four mango cultivars showed a declining rate of respiration and ethylene production. The single-and doubledose application of the hexanal formulation on the fruit surface exhibited a significant reduction in the rates of respiration and ethylene evolution compared to the untreated fruits. The respiration rate exhibited a twofold decline, and ethylene production reduced by three folds in the double-dose hexanal treated mango fruits stored under low temperature conditions compared to the ambient-stored untreated fruits (Control) (Figure 5A,B). 


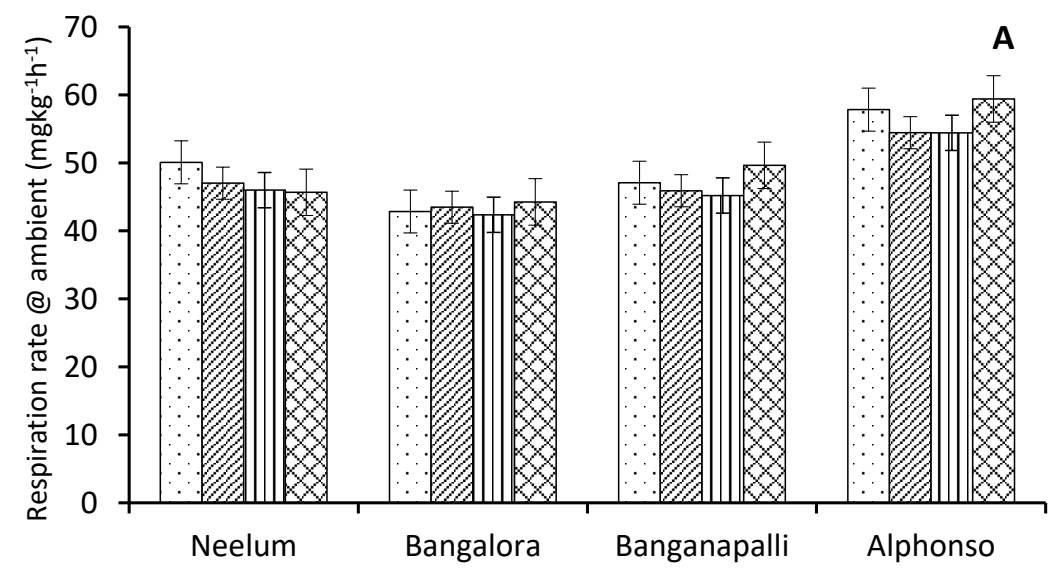

Hexanal spray at $\square 15 \mathrm{DBH} \quad \square 30 \mathrm{DBH} \square 15 \& 30 \mathrm{DBH}$ @ Control

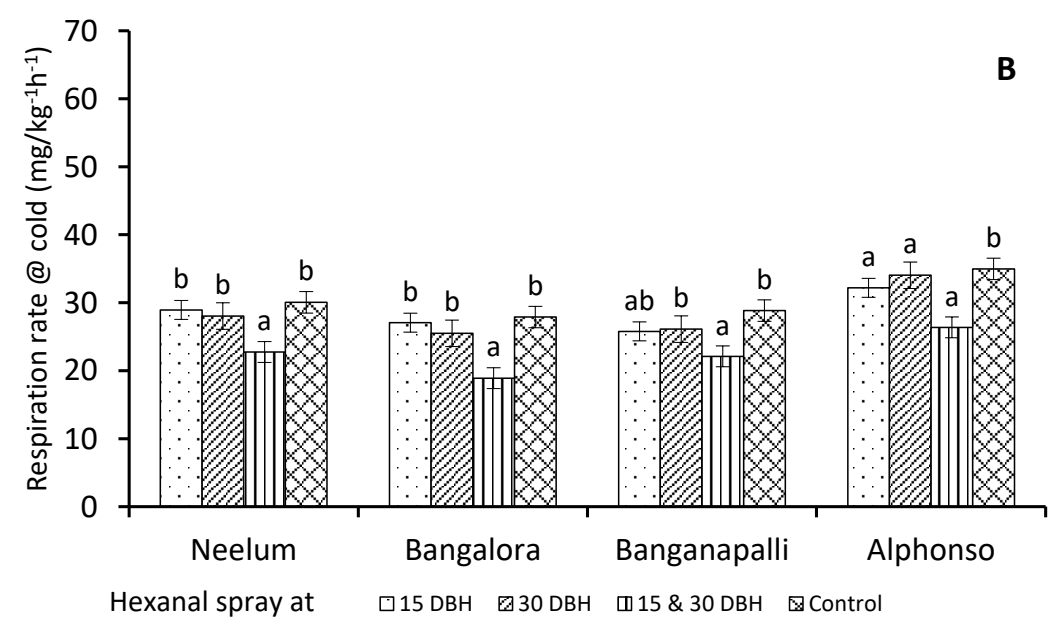

Figure 4. Mean respiration rate of the hexanal-treated and control mango fruit cultivars during the storage period in ambient (A) and cold (B) storage conditions. The vertical bars in the columns represent the standard error of four replicates $(n=15)$. Columns with different or the same letters indicate statistical significance and non-significance respectively $(p=0.05)$. DBH-Days before harvest.

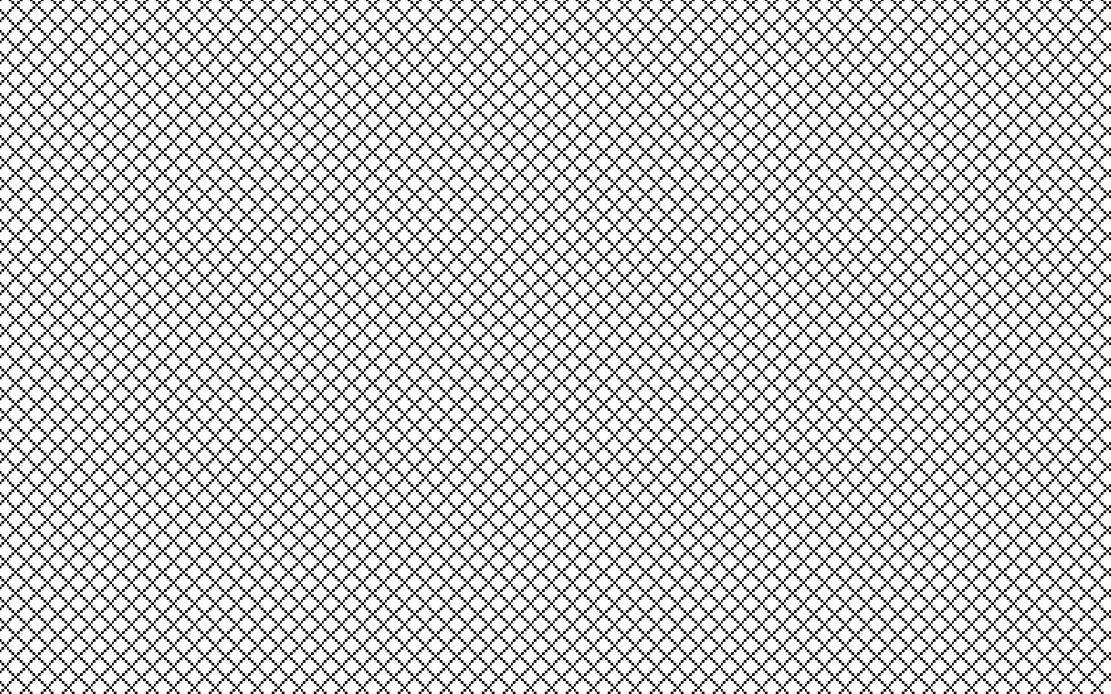

Figure 5. Cont. 


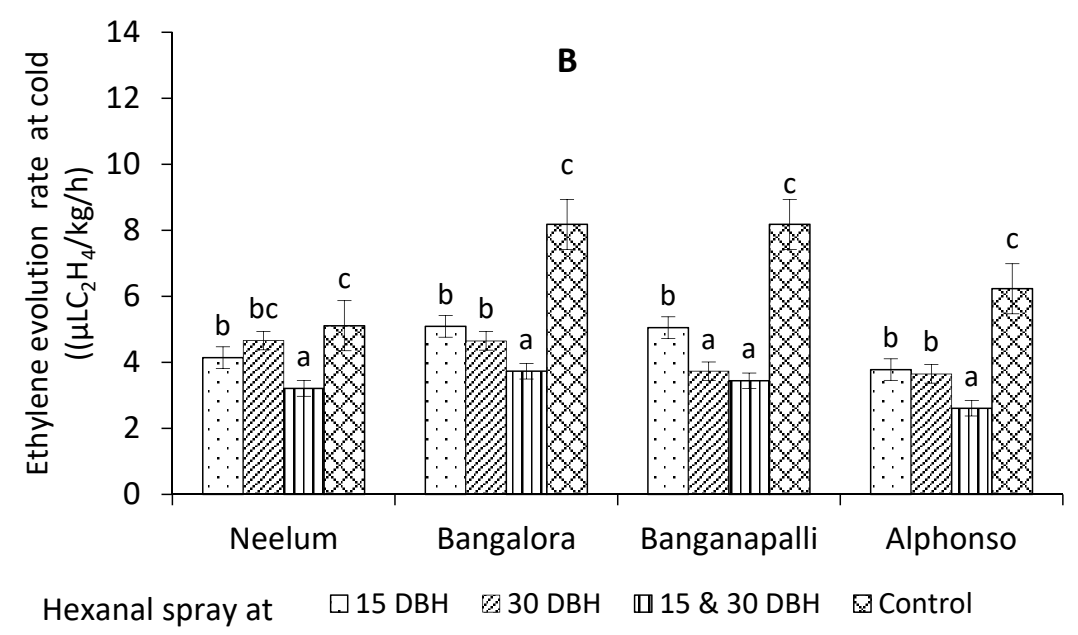

Figure 5. Mean ethylene evolution rate of the hexanal-treated and control mango fruit cultivars during the storage period in ambient (A) and cold (B) storage condition. The vertical bars in the columns represent the standard error of four replicates $(n=15)$. Columns with different and the same letters indicate statistical significance and non-significance, respectively $(p=0.05)$. DBH-Days before harvest.

\subsection{Biochemical Parameters}

During the storage period, the concentration of solutes present in the fruits differed among the mango cultivars, with the least total soluble solids (TSS) recorded in the cultivar Bangalora. Irrespective of their dosage, the hexanal coating increased the TSS in Neelum fruits compared to the untreated control (Table 2). The amount of total sugars present in the double-dose applied hexanal formulation-treated fruits increased significantly compared to that of the control fruits (Control) regardless of the storage conditions. Similarly to the TSS, the minimum amount of total sugars was noted in Bangalora (Table 1) fruits. The ascorbic acid in the mango fruits started declining during the post-harvest storage period irrespective of the treatment, cultivar or storage conditions (Table 3). Mango fruits imposed with the hexanal formulation treatments had no significance towards increasing the total carotenoids in Neelum and Banganapalli, but not in Bangalora and Alphonso (Table 3). The experimental results clearly indicate that the hexanal formulation had a significant effect in improving the fruit quality irrespective of the storage conditions, and their combinations had no significant effect on the irascorbic acid or total carotenoid content.

\subsection{Enzymatic Profiling of the Mango Fruits}

\subsubsection{Fruit Softening Enzymes}

The enzyme activities of the hexanal formulation-treated mango fruits (15 DBH, $30 \mathrm{DBH}$, and 15 and $30 \mathrm{DBH}$ ) under ambient and cold storage conditions were periodically observed from the harvest until 9 days of storage, and were compared with those of the untreated fruits (Control) in Neelum (Figure 6A-D), Bangalora, Banganapalli and Alphonso (supplementary file). The enzyme activity on the 0th and 9th day was compared, and was represented as a rate of change.

The fruit ripening coincided with the increased activity of enzymes related to fruit softening. The softening enzyme (PME and PG) activity of the mango fruits right after harvest had no significance among the treatments. A prominent upsurge in the activity of the enzymes started only during post-harvest storage period, irrespective of the hexanal formulation treatments, storage conditions and mango cultivars. The lower and gradual action of PME was recorded in Banganapalli, irrespective of the treatments and storage conditions, whereas the rate of increase in the PG activity was found to be non-significant among the different cultivars. Though the enzyme activities varied among different mango cultivars, the prominent action of hexanal formulation either as a single or double dose application decreased the enzyme activity irrespective of the cultivars and storage conditions (Figure 7A,B). 
Table 2. Influence of the hexanal formulation on the TSS and total sugars of mango cultivars under ambient and cold storage conditions.

\begin{tabular}{|c|c|c|c|c|c|c|c|c|c|c|c|c|c|c|c|c|}
\hline \multirow{3}{*}{$\begin{array}{c}\text { Hexanal } \\
\text { Spray } \\
\text { at }\end{array}$} & \multicolumn{8}{|c|}{ TSS $\left({ }^{\circ}\right.$ Brix $)$} & \multicolumn{8}{|c|}{ Total Sugars (\%) } \\
\hline & \multicolumn{2}{|c|}{ Neelum } & \multicolumn{2}{|c|}{ Bangalora } & \multicolumn{2}{|c|}{ Banganapalli } & \multicolumn{2}{|c|}{ Alphonso } & \multicolumn{2}{|c|}{ Neelum } & \multicolumn{2}{|c|}{ Bangalora } & \multicolumn{2}{|c|}{ Banganapalli } & \multicolumn{2}{|c|}{ Alphonso } \\
\hline & Ambient & Cold & $\begin{array}{l}\text { Ambient } \\
\text { (NS) }\end{array}$ & Cold & Ambient & Cold & $\begin{array}{l}\text { Ambient } \\
\text { (NS) }\end{array}$ & Cold & Ambient & Cold & Ambient & Cold & Ambient & Cold & Ambient & Cold \\
\hline $15 \mathrm{DBH}$ & $\begin{array}{l}20.98^{c} \\
\pm 0.13\end{array}$ & $\begin{array}{l}21.21^{b} \\
\pm 0.34\end{array}$ & $\begin{array}{c}15.71 \pm \\
0.21\end{array}$ & $\begin{array}{l}15.09^{b} \\
\pm 0.26\end{array}$ & $\begin{array}{l}23.27^{b} \\
\pm 0.15\end{array}$ & $\begin{array}{c}23.96^{\mathrm{ab}} \\
\pm 1.13\end{array}$ & $\begin{array}{c}23.94 \pm \\
0.24\end{array}$ & $\begin{array}{l}23.95^{b} \\
\pm 2.36\end{array}$ & $\begin{array}{l}16.64^{\mathrm{c}} \\
\pm 1.14\end{array}$ & $\begin{array}{l}16.51^{\mathrm{c}} \\
\pm 1.54\end{array}$ & $\begin{array}{l}13.96^{\mathrm{c}} \\
\pm 0.39\end{array}$ & $\begin{array}{l}13.66^{\mathrm{c}} \\
\pm 0.64\end{array}$ & $\begin{array}{l}16.48^{\mathrm{c}} \\
\pm 0.14\end{array}$ & $\begin{array}{l}16.82^{\mathrm{c}} \\
\pm 1.96\end{array}$ & $\begin{array}{l}17.53^{c} \\
\pm 1.86\end{array}$ & $\begin{array}{l}17.49^{\circ} \\
\pm 3.55\end{array}$ \\
\hline $30 \mathrm{DBH}$ & $\begin{array}{l}21.54^{\mathrm{b}} \\
\pm 0.22 \\
\end{array}$ & $\begin{array}{l}22.52^{\mathrm{a}} \\
\pm 0.28\end{array}$ & $\begin{array}{c}15.58 \pm \\
0.64\end{array}$ & $\begin{array}{l}14.65^{b} \\
\pm 1.25\end{array}$ & $\begin{array}{l}23.63^{\mathrm{b}} \\
\pm 0.74 \\
\end{array}$ & $\begin{array}{l}24.21^{\mathrm{a}} \\
\pm 0.12\end{array}$ & $\begin{array}{c}23.94 \pm \\
0.89\end{array}$ & $\begin{array}{c}24.12^{\mathrm{ab}} \\
\pm 1.54\end{array}$ & $\begin{array}{l}17.36^{\mathrm{b}} \\
\pm 2.21 \\
\end{array}$ & $\begin{array}{l}18.00^{\mathrm{b}} \\
\pm 0.14 \\
\end{array}$ & $\begin{array}{l}14.54^{\mathrm{b}} \\
\pm 0.75\end{array}$ & $\begin{array}{l}15.12^{b} \\
\pm 0.12\end{array}$ & $\begin{array}{l}20.47^{b} \\
\pm 3.77 \\
\end{array}$ & $\begin{array}{l}20.53^{\mathrm{b}} \\
\pm 0.52 \\
\end{array}$ & $\begin{array}{l}20.29 \mathrm{~b} \\
\pm 0.24 \\
\end{array}$ & $\begin{array}{l}19.90^{\mathrm{b}} \\
\pm 0.48\end{array}$ \\
\hline $\begin{array}{l}15 \text { and } \\
30 \mathrm{DBH}\end{array}$ & $\begin{array}{l}22.29^{a} \\
\pm 0.02\end{array}$ & $\begin{array}{l}22.84^{\mathrm{a}} \\
\pm 0.13\end{array}$ & $\begin{array}{c}15.45 \pm \\
0.71\end{array}$ & $\begin{array}{l}15.07^{b} \\
\pm 0.69\end{array}$ & $\begin{array}{l}24.37^{\mathrm{a}} \\
\pm 0.96\end{array}$ & $\begin{array}{l}24.32^{\mathrm{a}} \\
\pm 0.45\end{array}$ & $\begin{array}{c}23.85 \pm \\
1.74\end{array}$ & $\begin{array}{c}24.10^{\mathrm{ab}} \\
\pm 0.89\end{array}$ & $\begin{array}{l}20.62^{\mathrm{a}} \\
\pm 0.98\end{array}$ & $\begin{array}{l}20.80^{\mathrm{a}} \\
\pm 0.24\end{array}$ & $\begin{array}{l}16.95^{\mathrm{a}} \\
\pm 1.25\end{array}$ & $\begin{array}{l}17.19^{\mathrm{a}} \\
\pm 0.59\end{array}$ & $\begin{array}{l}22.91^{\mathrm{a}} \\
\pm 0.26\end{array}$ & $\begin{array}{l}22.45^{\mathrm{a}} \\
\pm 0.54\end{array}$ & $\begin{array}{l}21.06^{\mathrm{a}} \\
\pm 1.54 \\
\end{array}$ & $\begin{array}{l}20.91^{a} \\
\pm 2.19\end{array}$ \\
\hline Control & $\begin{array}{c}17.80^{\mathrm{d}} \\
\pm 0.11\end{array}$ & $\begin{array}{l}18.25^{\mathrm{c}} \\
\pm 1.12\end{array}$ & $\begin{array}{c}15.66 \pm \\
0.18\end{array}$ & $\begin{array}{l}15.51^{\mathrm{a}} \\
\pm 0.65\end{array}$ & $\begin{array}{l}23.37^{\mathrm{b}} \\
\pm 1.15\end{array}$ & $\begin{array}{l}23.68^{c} \\
\pm 0.78\end{array}$ & $\begin{array}{c}23.99 \pm \\
2.56\end{array}$ & $\begin{array}{l}24.26^{\mathrm{a}} \\
\pm 0.45\end{array}$ & $\begin{array}{l}15.78^{\mathrm{d}} \\
\pm 0.74\end{array}$ & $\begin{array}{l}15.65^{\mathrm{d}} \\
\pm 0.58\end{array}$ & $\begin{array}{l}11.17^{\mathrm{d}} \\
\pm 0.25\end{array}$ & $\begin{array}{l}11.86^{\mathrm{d}} \\
\pm 1.27\end{array}$ & $\begin{array}{l}15.45^{\mathrm{d}} \\
\pm 0.02\end{array}$ & $\begin{array}{l}16.02^{\mathrm{d}} \\
\pm 1.54\end{array}$ & $\begin{array}{l}17.54^{c} \\
\pm 0.64\end{array}$ & $\begin{array}{l}17.54 \\
\pm 0.14\end{array}$ \\
\hline
\end{tabular}

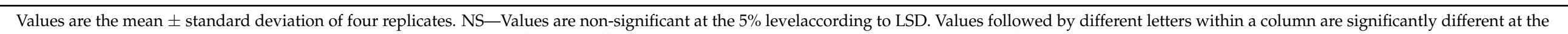

$5 \%$ level according to LSD. Values with the same letters are not significantly different at the $5 \%$ level according to LSD. DBH-Days before harvest.

Table 3. Influence of hexanal formulation on ascorbic acid and the total carotenoids of mango cultivars under ambient and cold storage conditions.

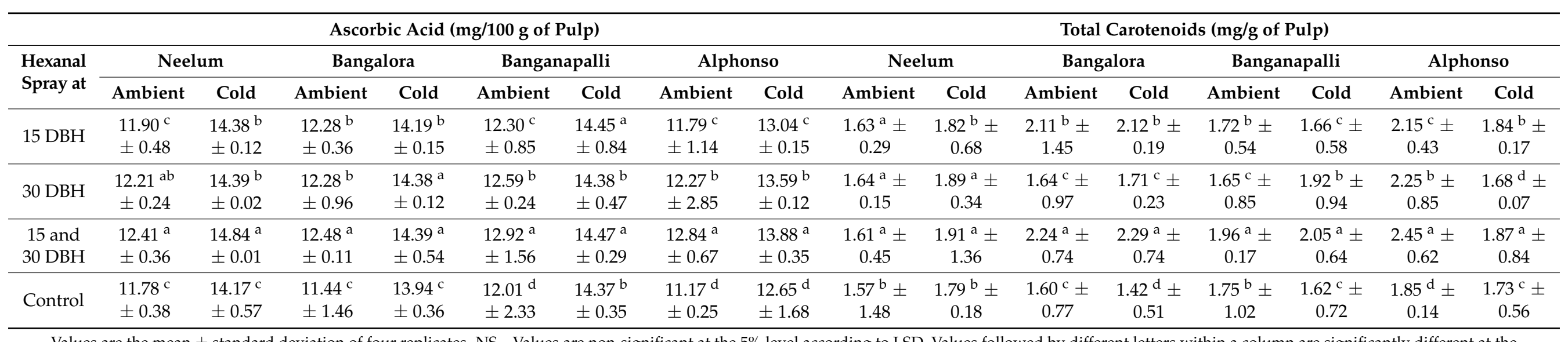

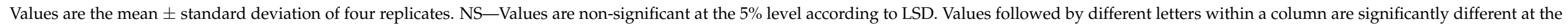

$5 \%$ level according to LSD. Values with the same letters are not significantly different at the $5 \%$ level according to LSD. DBH-Days before harvest. 


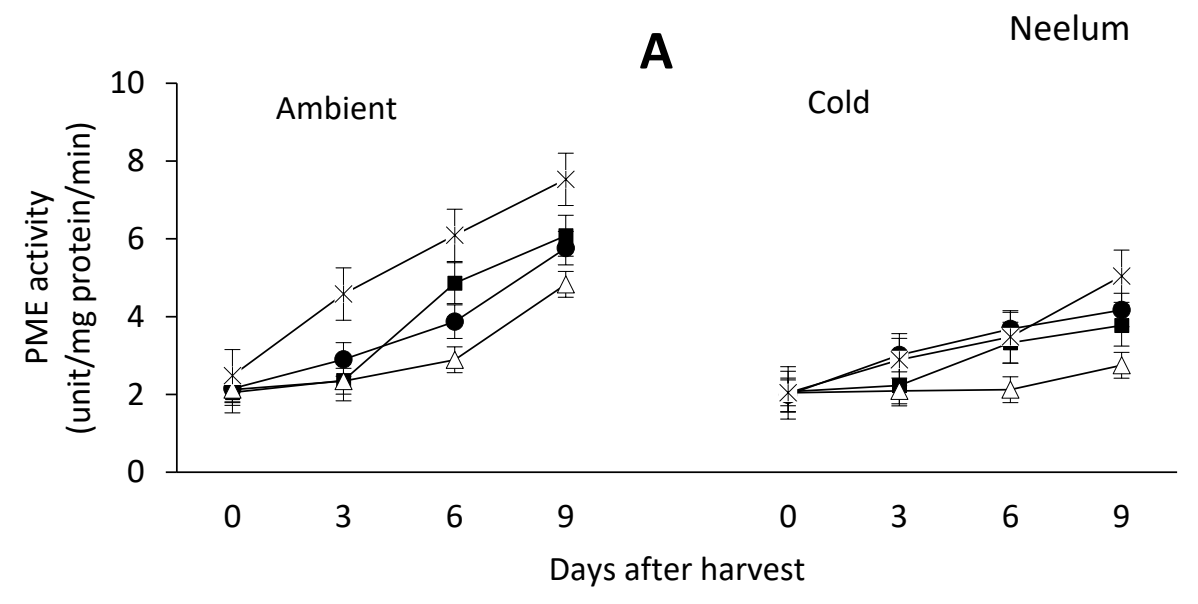

Hexanal spray at $\multimap 15 \mathrm{DBH} \longrightarrow-30 \mathrm{DBH} \longrightarrow-15 \& 30 \mathrm{DBH} \quad-*-$ Control

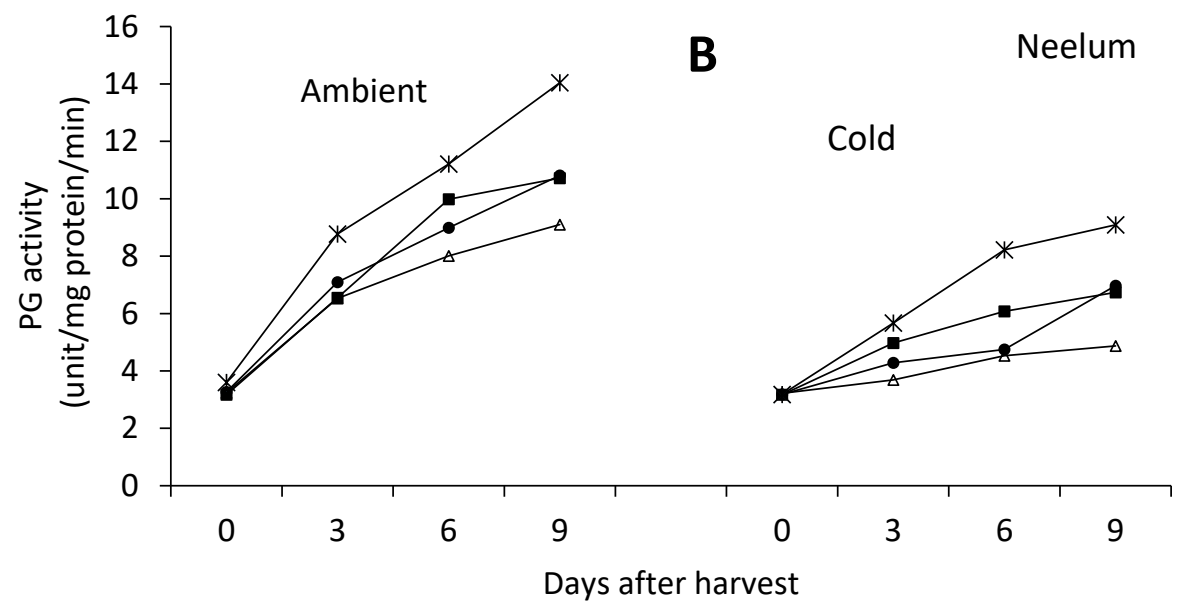

Hexanal spray at $\rightarrow 15 \mathrm{DBH} \rightarrow 30 \mathrm{DBH} \rightarrow 15 \& 30 \mathrm{DBH} \rightarrow$ Control

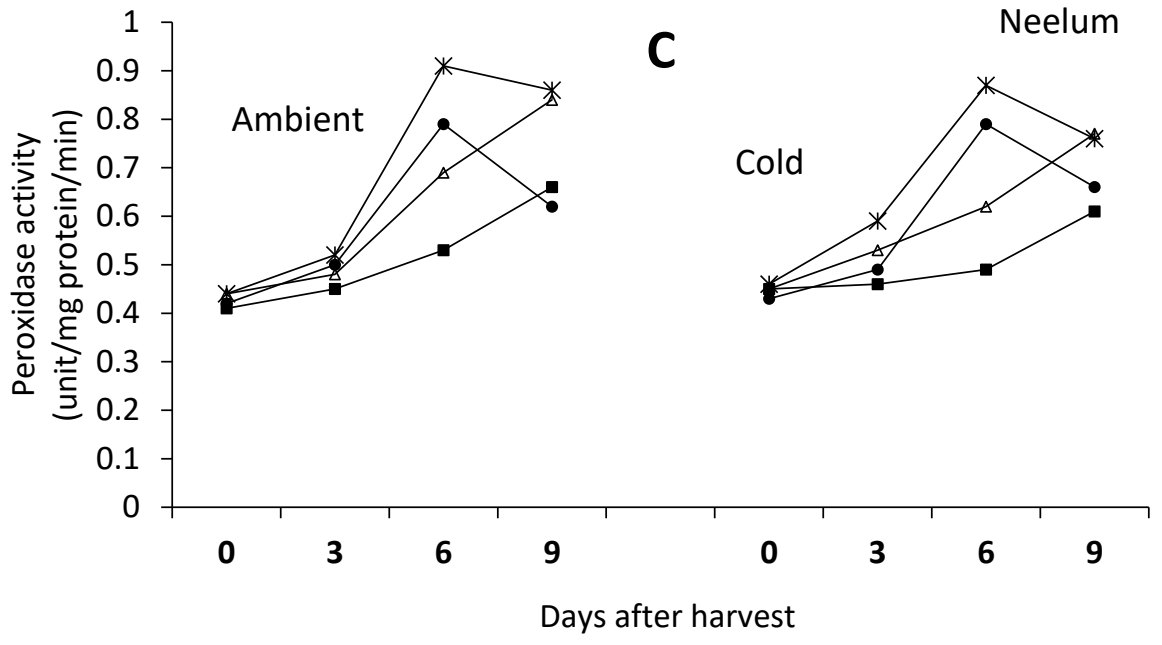

Hexanal spray at $\longrightarrow 15 \mathrm{DBH} \rightarrow-30 \mathrm{DBH} \rightarrow 15 \& 30 \mathrm{DBH} \rightarrow$ Control

Figure 6. Cont. 


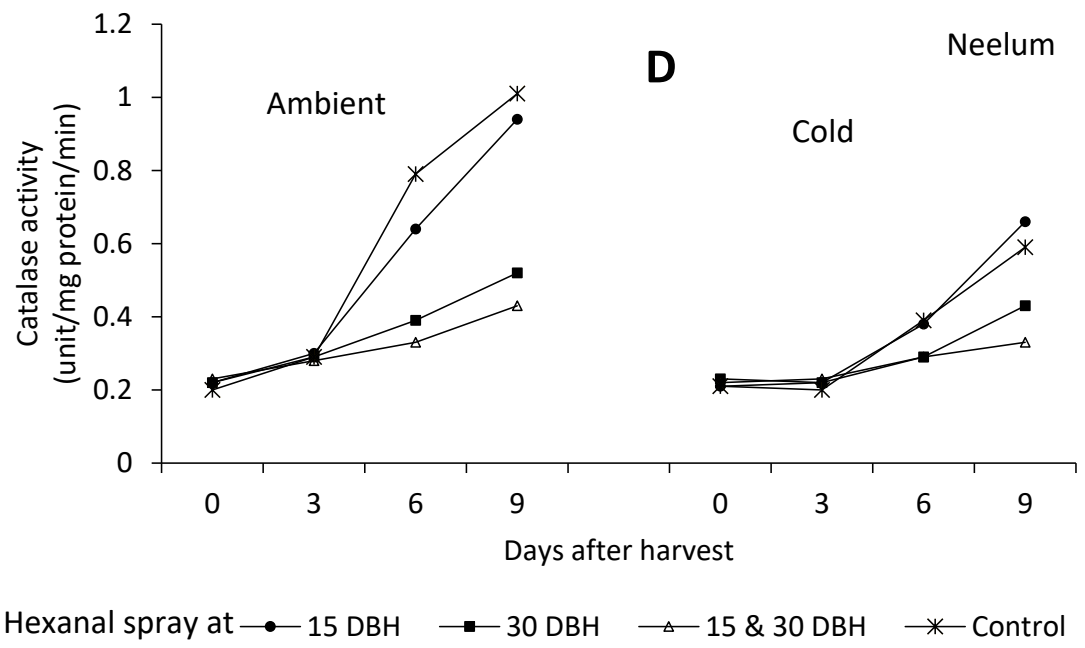

Figure 6. Periodical changes in the PME (A), PG (B), Peroxidase (C) and Catalase (D) activities of the hexane-treated and control mango fruit cv. Neelum during storage under ambient and cold storage conditions (up to 9 days). The vertical bars represent the mean value of four replicates. PME-Pectinmethylesterase; PG-Polygalacturonase.
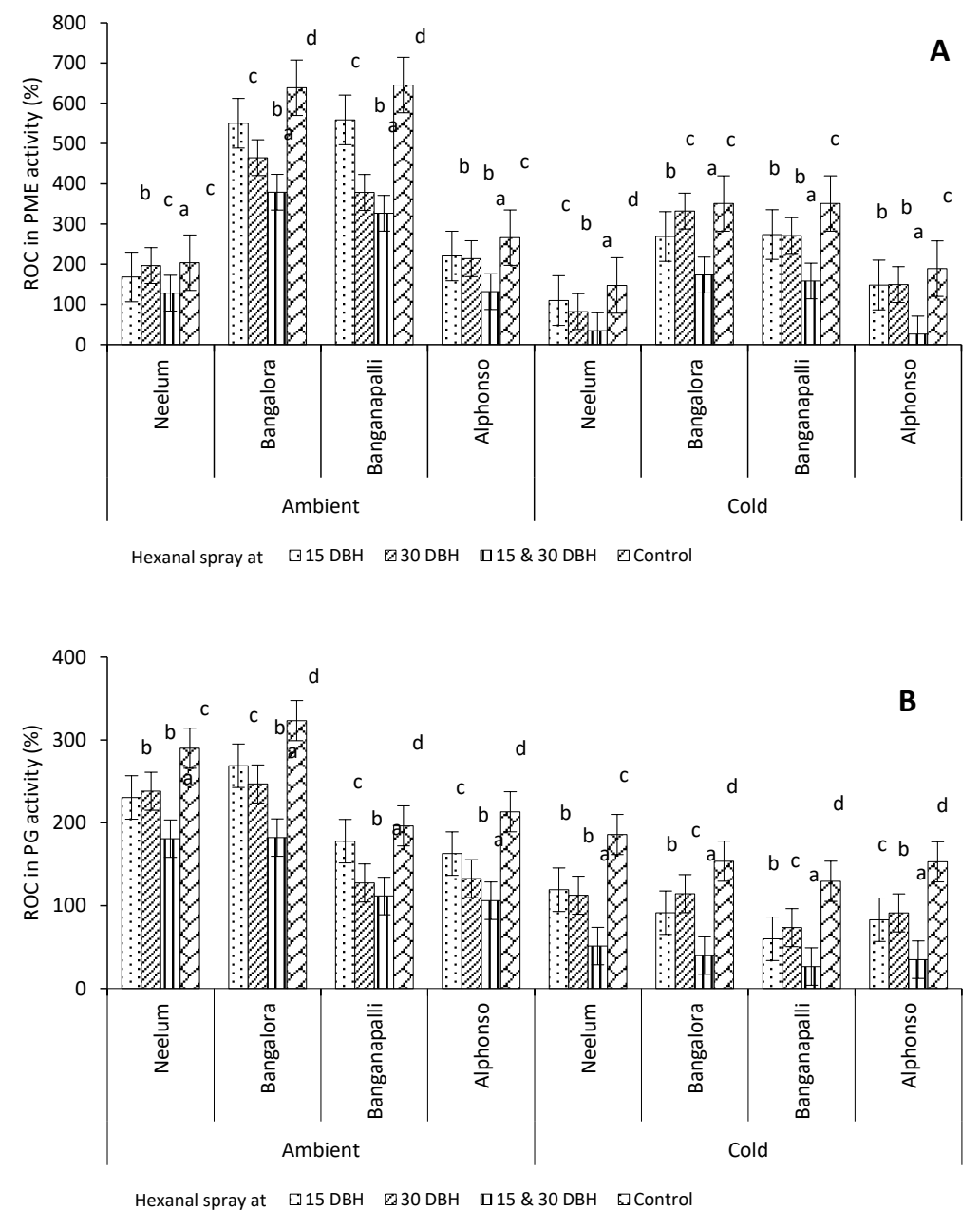

Figure 7. Percentage rate of change in the PME (A) and PG activity (B) of hexanal-treated and control mango fruits stored under ambient and cold conditions. The vertical bars in the columns represent the standard error of four replicates. Columns with different and the same letters indicate statistical significance and non-significance, respectively $(p=0.05)$. DBH—Days before harvest; ROC—Rate of change. 


\subsubsection{Antioxidant Enzymes}

The antioxidant property is the most predominant factor to be studied from the health point of view. The lowest antioxidant enzyme activity maximizes the retention of antioxidant properties in fruits and vegetables. In mango, though the antioxidant enzyme activity was increased due to the time of storage, hexanal formulation profoundly reduces their rate of change irrespective of the varieties and storage conditions (Figure 8A,B). The activity of peroxidase and Catalase up surged at a tremendous rate in the control fruits compared to the hexanal formulation-treated fruits. Among the varieties, Neelum is expected to have less antioxidant enzyme activity compared to the other varieties used in the experiment. The mango varieties Banganapalli and Alphonso had the highest rate of enzymatic changes under ambient and cold storage conditions. The hexanal formulation integrated with cold storage conditions had a positive influence in bringing down the antioxidant enzyme activity irrespective of its dose.
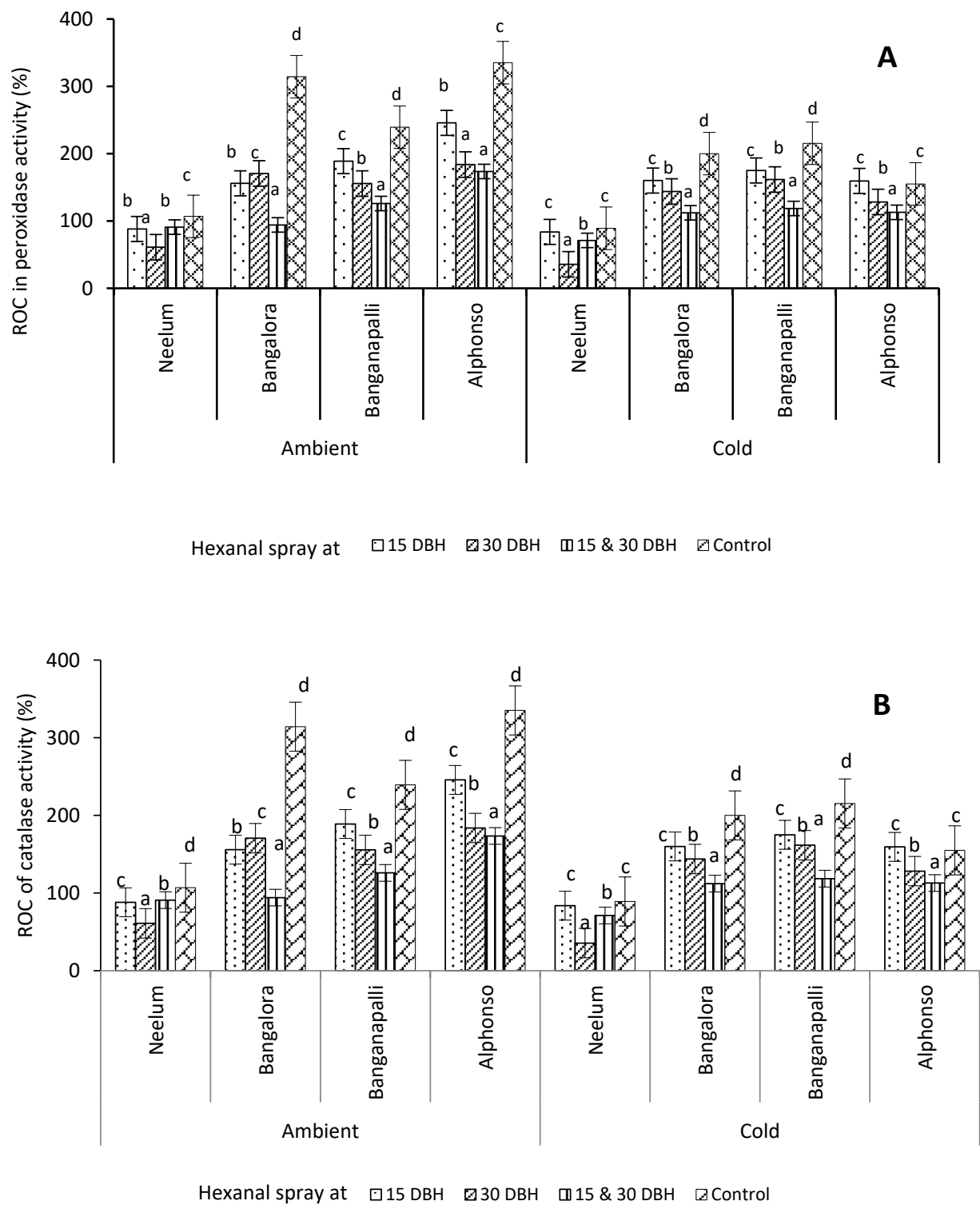

Figure 8. Percentage rate of change in the peroxidase (A) and catalase activity (B) of the hexanaltreated and control mango fruits stored under ambient and cold conditions. The vertical bars in columns represent the standard error of four replicates. Columns with different and same letters indicate statistical significance and non-significance, respectively $(p=0.05)$. DBH-Days before harvest; ROC—Rate of change. 


\section{Discussion}

The post-harvest life of perishable commodities such as fruits is dependent on several external and internal factors. An appropriate understanding of these factors would help in the development of strategies to overcome the problems leading to poor shelf life. Mango is the major commercial fruit crop of India, with about $25-35 \%$ of harvested fruits being wasted due to various improper post-harvest handling practices. Hence, any favorable results that could overcome the poor marketable life would help the economy of growers as well as the nation.

Although the infection starts prior to harvest, the storage environmental factors, coupled with the rapid conversion of starch to sugars and the loss of organic acids and polyphenols in most of horticultural commodities, especially fruits and vegetables, make them conducive for attack by microorganisms causing various post-harvest diseases [22]. However, due to the limited number of registered fungicides and the restriction on their concentration for residual levels in food commodities, the application of botanicals or plant extracts in the domain of post-harvest handling is quite encouraging.

Hexanal, a six carbon aldehyde, is one such dominant compound released naturally by plant material through the lipoxygenase pathway from linoleic acid after tissue damage. It is an important precursor for the formation of six carbon alcohols and esters, and it has been found to extend the freshness of fruit by inhibiting the enzyme phospholipase-D, which is involved in fruit deterioration [5,6,12].Hexanal was chosen to study its impact on mango fruits, as the benefits due to its application have been documented in various other horticultural crops, and because of its generally-regarded-as-safe status (GRAS) $[5,6]$. The fruits at the crown region of mango trees are completely drenched with the hexanal formulation as a pre-harvest surface treatment, and this influences the metabolic activities, enhancing the shelf life and quality after harvest due to its absorption by the leaves, especially fruits and stalks with the minor volatilization of hexanal to atmosphere as a limiting factor $[6,23]$.

The ripening phase of the mango fruit is associated with the change in its peel color from green to yellowish orange, and the increase in its sugars, TSS, ethylene evolution rate, respiration rate and PLW, and the decrease in its firmness due to disintegrated cell wall substances like pectin [6,24].

The loss in weight of the fruits during storage is attributed primarily to weight loss aided by respiration and temperature directly. Very low PLW ranging between 3 to $6 \%$ was recorded on average in all of the cultivars under cold storage with a double application of the hexanal formulation treatment, as compared to the 10 to $13 \%$ PLW of control fruits under ambient conditions. The data clearly showed that the influence of the hexanal formulation may not be the direct cause of the reduced PLW, as only a slight decline in the PLW in the treated fruits was observed. However, compared to cold storage, a steep reduction in PLW was noticed in ambient conditions irrespective of the cultivars studied. The obtained weight loss result did not coincide with the statement obtained in mango fruits [7]; wax acts a barrier of gas exchange and water loss [5,25], and may be detoriated by the components present in the hexanal formulation spray fluid/the presence of hexanal might slow down the PLW, resulting in comparable results of the treated fruits with the control irrespective of their storage conditions.

Fruit firmness is one of the prime parameters that determine the quality for various unit operations, from the table to industrial purposes. The major textural changes resulting in the softening of fruits are due to the enzyme-mediated alteration in the structure and composition of the cell wall, i.e., the partial or complete solubilization of cell wall polysaccharide (pectins and celluloses) [26-28]. Polygalacturanase, along with PME, promotes cell wall disintegration, which could lead to higher PLW and a loss of firmness. An examination of the PG and PME activities in relation to fruit firmness clearly demonstrated anegative correlation with the fruit firmness and PLW, ultimately affecting the fruit freshness and storage life.

As compared to the average firmness value of $15 \mathrm{~N} / \mathrm{cm}^{2}$, the hexanal formulationtreated fruits registered a value of 18 to $22 \mathrm{~N} / \mathrm{cm}^{2}$. Correspondingly, the changing rate of 
PME activity for the treated and control fruits varied from 1.14 to $7.23 \mathrm{unit} / \mathrm{mg}$ protein $/ \mathrm{min}$ and 1.24 to $9.16 \mathrm{unit} / \mathrm{mg}$ protein/min, respectively, while the decreasing trend of the PG activity ranged from 3.10 to $15.07 \mathrm{unit} / \mathrm{mg}$ protein/min for the hexanal formulationtreated and control fruits, irrespective of the cultivars and storage conditions. The hexanal treatment, in general, maintained the firmness of the different cultivars during the storage period, indicating that pre-harvest sprays of the hexanal formulation may be responsible for slowing down the cell wall softening enzymes responsible for texture loss.

Mango exhibits a typical climacteric pattern of ripening. Any reduction in its respiratory rate delays the ripening process. The reduction in the respiration rate during storage due to hexanal treatment in the four cultivars was to an extent of $43 \%$ to $70 \%$ (18 to $59 \mathrm{mgCO}_{2} / \mathrm{kg} / \mathrm{h}$ as compared to control. The respiratory rate declined more than $50 \%$ under cold storage compared to ambient storage in all of the four cultivars. In several storage studies, the respiratory rate was found to be reduced under cold storage conditions. The reduction is possibly because of the reduced activities of enzymes involved in catalytic respiration $[29,30]$. Similarly, the rate of ethylene evolution in the four cultivars during storage was reduced to a range of 48 to $70 \%$ due to the hexanal treatment coupled with cold storage, as compared to the control fruits under ambient storage. The reduction in the ambient conditions was to an extent of 20 to $22 \%$, clearly demonstrating the effect of cold storage and the influence of temperature on the ethylene evolution rate [31].

The fruit quality parameters recorded at the end of storage life (9th day) evidenced high total sugars with the double-dose application of the hexanal formulation spray compared with the control fruits. The TSS and total sugars followed a gradual increasing trend during the initial storage, followed by a gradual decline, and vice-versa for organic acids $[6,32,33]$. The starch granules being hydrolyzed into sugars may presumably become exhausted during the later stages of ripening [34].Our results clearly demonstrated that the total sugars of the hexanal formulation-treated fruits were significantly high, but there were no significant changes in TSS and ascorbic acid content, which might be due to the proportionate increase in starch granules for hydrolysis, and the negative impact over other soluble solids.

The visual appeal is one of the important parameters that define consumers' preferences. The development of a yellow or red color is positively correlated with total carotenoid content. The changes observed in the mango fruits were positively correlated with the total carotenoids, and respectively increased with ripening [32]. The mango fruits subjected to hexanal formulation spray attained significant color development due to the presence of hexanal. Though hexanal is known for its characteristic retention of green color in many fruits [7,33], our data evidenced a positive acceleration of carotenoid synthesis in the sprayed fruits, while this was unseen in the untreated control fruits. Thus, the experiment confirmed the impact of the hexanal formulation on mango fruits in terms of enhancing their storage life and fruit quality.

Peroxidase and catalase are known for their involvement in fruit ripening. The average peroxidase activity at the 0th day of storage was recorded as $0.35 \mathrm{unit} / \mathrm{mg}$ protein $/ \mathrm{min}$; hexanal effectively brought down the peroxidase activity from $1.61 \mathrm{unit} / \mathrm{mg}$ protein $/ \mathrm{min}$ to $0.61 \mathrm{unit} / \mathrm{mg}$ protein/min invariably with its dose. Sweet cherry, in which hexanal effect is widely studied, recorded a low enzyme activity similar to this experiment [35]. Contrastingly, hexanal-induced enzyme activity was also recorded in sweet cherry [30]. However, in mango, our results, i.e., minimized enzyme activity due to hexanal, were supported by previous researchers' work [7]. Because similar kinds of results were observed in both ambient and cold storage conditions, it is hypothesized that that hexanal prevented the formation of free radicals by indirect mechanisms, and hence slowing or limited activity of peroxidase was experienced.

Between the two storage conditions, the rate of change in the peroxidase activity was high in fruits stored at ambient conditions compared to low-temperature storage. This may be because of the temperature-dependent characteristic of peroxidase enzyme [36]. 
In this study, the catalase activity was registered as being higher in untreated fruits compared (1.09 unit/mg protein/min) to the hexanal formulation-treated fruits under ambient storage conditions $(0.43 \mathrm{unit} / \mathrm{mg}$ protein $/ \mathrm{min})$. The rate of change in the catalase activity was obvious after three days in fruits subjected to both spray and dip treatments under ambient conditions. There was also a definite pronounced impact of cold storage on the catalase activity. Irrespective of the cultivars, fruits subjected to a pre-harvest spray of the hexanal formulation followed a similar trend under cold storage condition as that of ambient storage. A similar reduction in catalase was earlier reported in hexanal-treated mango [7] and 1-MCP-treated Asian Pear [37,38].

\section{Conclusions}

The study ensured that the fruit surface treatment of hexanal effectively delayed the ripening and enhanced the quality during post-harvest storage of mango fruits. A pre-harvest spray with a double dose application of the hexanal formulation followed by cold storage (Temperature $-13{ }^{\circ} \mathrm{C}$; Relative Humidity-90 $\pm 3 \%$ ) had increased the storage life of mango fruits from five days to twenty days, and the hexanal at single and double dose applications subsequently brought down the action of the tissue-softening enzymes and preserved the integral membrane stability, thus maintaining the fruit firmness and other postharvest qualities related to taste and pulp color.

Supplementary Materials: The following are available online at https:/ /www.mdpi.com/article/10 .3390 / coatings11101267/s1, Figure S1: Periodically changes in Pectinmethylesterase, Catalase and peroxidase activities of hexanal formulation treated and control mango fruits during storage under ambient and cold storage conditions (up to 9 days).

Author Contributions: Conceptualization, P.P., K.S., K.S.S., G.P. and J.S.; methodology, P.P., G.P.; validation, K.S. and K.S.S.; formal analysis, P.P. and K.S.; software, P.P. and S.V.R.R.; investigation, K.S., A.S., K.S.S., G.P. and J.S.; writing-original draft preparation, P.P., K.S.; writing-review and editing, K.S., G.P.,S.V.R.R. and K.S.S.; supervision, K.S., A.S., K.S.S., G.P. and J.S. All authors have read and agreed to the published version of the manuscript.

Funding: The authors acknowledge the International Development Research Centre (IDRC), Centre for Research and Development International (CRDI) and Canadian International Development Agency Ottawa, for financial support throughout the research period under the grant No. 106931-002.

Institutional Review Board Statement: Not applicable.

Informed Consent Statement: Not applicable.

Data Availability Statement: Data contained within the article.

Acknowledgments: The authors thank the mango growers' Santha Kumar, Chittrarasu and Nagaraj. The authors also thank the Department of Nano Science and Technology, Tamil Nadu Agricultural University, for providing the lab facilities for this study.

Conflicts of Interest: The authors declare no conflict of interest. The funders had no role in the design of the study; in the collection, analyses, or interpretation of data; in the writing of the manuscript, or in the decision to publish the results.

\section{References}

1. Akamine, E.K.; Goo, T. Respiration and ethylene production during ontogeny of fruit. J. Am. Soc. Hortic. Sci. 1973, 98, 381-383.

2. Mohammed, M.; Mpagalile, J.; Lopez, V. Mango value chain in Trinida Guyana and St. Lucia: Measure post-harvest losses. J. Postharvest Technol. 2018, 6, 001-013.

3. Ntsoane, M.L.; Zude-Sasse, M.; Mahajan, P.; Sivakumar, D. Quality assesment and postharvest technology of mango: A review of its current status and future perspectives. Sci. Hortic. 2019, 249, 77-85. [CrossRef]

4. Chaplin, G.R. Advances in Post-Harvest Physiology of Mango. Acta Hortic. 1989, 639-648. [CrossRef]

5. Paliyath, G.; Pinhero, R.G.; Yada, R.; Murr, D.P. Effect of processing conditions on phospholipase d activity of corn kernel subcellular fractions. J. Agric. Food Chem. 1999, 47, 2579-2588. [CrossRef] [PubMed]

6. Paliyath, G.; Murr, D.P. Compositions for the Preservation of Fruits and Vegetables. U.S. Patent 7,198,811,B2, 3 April 2007. 
7. Anusuya, P.; Nagaraj, R.; Janavi, G.J.; Subramanian, K.S.; Paliyath, G.; Subramanian, J. Pre-harvest sprays of hexanal formulation for extending retention and shelf-life of mango (Mangifera indica L.) fruits. Sci. Hortic. 2016, 211, 231-240. [CrossRef]

8. Jincy, M.; Djanaguiraman, M.; Jeyakumar, P.; Subramanian, K.; Jayasankar, S.; Paliyath, G. Inhibition of phospholipase denzyme activity through hexanal leads to delayed mango (Mangifera indica L.) fruit ripening through changes in oxidants and antioxidant enzymes activity. Sci. Hortic. 2017, 218, 316-325. [CrossRef]

9. Gill, K.; Dhaliwal, H.; Mahajan, B.; Paliyath, G.; Boora, R. Enhancing postharvest shelf life and quality of guava (Psidium guajava L.) cv. Allahabad Safeda by pre-harvest application of hexanal containing aqueous formulation. Postharvest Biol. Technol. 2016, 112, 224-232. [CrossRef]

10. Venkatachalam, K.; Muthuvel, I.; Sundaresan, S.; Subramanian, K.S.; Janaki, J.G.; Sullivan, J.A.; Paliyath, G.; Subramanian, J.J.T.A. Post-harvest dip of enhanced freshness formulation to extend the shelf life of banana (Musa acuminata cv. Grand Naine) in India. Trop. Agric. 2018, 95, 1-13.

11. Preethi, P.; Soorianathasundaram, K.; Sadasakthi, A.; Subramanian, K.; Paliyath, G.; Subramanian, J. Influence of hexanal formulation on storage life and post-harvest quality of mango fruits. J. Environ. Biol. 2018, 39, 1006-1014. [CrossRef]

12. Paliyath, G.; Subramanian, J. Phospholipase D Inhibition Technology for Enhancing Shelf Life and Quality; Wiley-Blackwel: Hoboken, IA, USA, 2008; p. 240.

13. Mohan, C.; Sridharan, S.; Gunasekaran, K.; Subramanian, K.; Natarajan, N.J.J.E.Z.S. Biosafety of hexanal as nanoemulsion on egg parasitoid Trichogramma spp. J. Entomol. Zool. Stud. 2017, 5, 1541-1544.

14. Jha, S.N.; Jaiswal, P.; Narsaiah, K.; Kaur, P.P.; Singh, A.K.; Kumar, R. Textural properties of mango cultivars during ripening. J. Food Sci. Technol. 2013, 50, 1047-1057. [CrossRef] [PubMed]

15. Hedge, J.E.; Hofreiter, B.T. Carbohydrates Chemistry; Academic Press: New York, NY, USA, 1962.

16. Chemists, A.; Horwitz, W. Official Methods of Analysis; Association of Official Analytical Chemists: Washington, DC, USA, 1975; Volume 222.

17. Jensen, A. Handbook of Physiological Methods; Cambridge University Press: New York, NY, USA, $1978 ;$ p. 70.

18. Hagerman, A.E.; Austin, P.J.; Chemistry, F. Continuous spectrophotometric assay for plant pectin methyl esterase. J. Agric. Food Chem. 1986, 34, 440-444. [CrossRef]

19. Ali, Z.; Brady, C. Purification and Characterization of the Polygalacturonases of Tomato Fruits. Funct. Plant Biol. 1982, 9, 155-169. [CrossRef]

20. Malik, C.P.; Singh, M. Plant Enzymology and Histo-Enzymology; Kalyani Publishers: New Delhi, India, 1980.

21. Luck, H. Estimation of Catalase Activity; Academic Press: Cambridge, MA, USA, 1974; p. 885.

22. Caruso, F.L.; Ramsdell, D.C. Compendium of Blueberry and Cranberry Diseases; APS Press: Eagan, MN, USA, 1995.

23. Reddy, S.; Sharma, R.; Srivastava, M.; Kaur, C. Effect of pre-harvest application of salicylic acid on the postharvest behavior of 'amrapali' mango fruits during storage. Ind. J. Hortic. 2016, 73, 405-409. [CrossRef]

24. Song, J.; Leepipattanawit, R.; Deng, W.; Beaudry, R.M. Hexanal Vapor Is a Natural, Metabolizable Fungicide: Inhibition of Fungal Activity and Enhancement of Aroma Biosynthesis in Apple Slices. J. Am. Soc. Hortic. Sci. 1996, 121, 937-942. [CrossRef]

25. Hoa, T.T.; Ducamp, M. Effects of different coatings on biochemical changes of 'cat Hoaloc'mangoes in storage. Postharvest Biol. Technol. 2008, 48, 150-152. [CrossRef]

26. Bhagyalakshmi, N.; Prabha, T.; Yashodha, H.; Prasanna, V.; Jagadeesh, B.; Tharanathan, R. Biochemical studies related to textural regulation during ripening of banana and mango fruit. Acta Hortic. 2002, 717-724. [CrossRef]

27. Jha, S.; Kingsly, A.; Chopra, S. Physical and mechanical properties of mango during growth and storage for determination of maturity. J. Food Eng. 2006, 72, 73-76. [CrossRef]

28. Reddy, S.V.R.; Sharma, R.R.; Barthakur, S. Influence of 1-MCP on texture, related enzymes, quality and their relative gene expression in 'Amrapali' mango (Mangifera indica L.) fruits. J. Food Sci. Technol. 2017, 54, 4051-4059. [CrossRef]

29. Yamashita, F.; Benassi, M.; Kieckbusch, T.J.T.S. Shelf life extension of individually film-wrapped mangoes. Trop. Sci. 1997, 37, 249-255.

30. Sharma, M.; Jacob, J.K.; Subramanian, J.; Paliyath, G. Hexanal and 1-MCP treatments for enhancing the shelf life and quality of sweet cherry (Prunus avium L.). Sci. Hortic. 2010, 125, 239-247. [CrossRef]

31. Zerbini, P.E.; Vanoli, M.; Rizzolo, A.; Grassi, M.; Pimentel, R.M.D.A.; Spinelli, L.; Torricelli, A. Optical properties, ethylene production and softening in mango fruit. Postharvest Biol. Technol. 2015, 101, 58-65. [CrossRef]

32. Mercadante, A.Z.; Rodriguez-Amaya, D.B.; Chemistry, F. Effects of ripening, cultivar differences, and processing on the carotenoid composition of mango. J. Agric. Food Chem. 1998, 46, 128-130. [CrossRef]

33. Artés-Hernández, F.; Artés, F.; Tomás-Barberán, F.A.; Chemistry, F. Quality and enhancement of bioactive phenolics in cv. Napoleon table grapes exposed to different postharvest gaseous treatments. J. Agric. Food Chem. 2003, 51, 5290-5295. [CrossRef]

34. Subedi, P.; Walsh, K. Assessment of sugar and starch in intact banana and mango fruit by SWNIR spectroscopy. Postharvest Biol. Technol. 2011, 62, 238-245. [CrossRef]

35. Gonçalves, B.; Correia, C.M.; Silva, A.P.; Bacelar, E.; Santos, A.; Ferreira, H.M.F.; Moutinho-Pereira, J.M. Variation in xylem structure and function in roots and stems of scion-rootstock combinations of sweet cherry tree (Prunus avium L.). Trees 2006, 21, 121-130. [CrossRef] 
36. Yingsanga, P.; Srilaong, V.; Kanlayanarat, S.; Noichinda, S.; McGlasson, W. Relationship between browning and related enzymes (PAL, PPO and POD) in rambutan fruit (Nephelium lappaceum Linn.) cvs. Rongrien and See-Chompoo. Postharvest Biol. Technol. 2008, 50, 164-168. [CrossRef]

37. Yazdani, N.; Arzani, K.; Mostofi, Y.; Shekarchi, M. $\alpha$-Farnesene and antioxidative enzyme systems in Asian pear (Pyrus serotina Rehd.) fruit. Postharvest Biol. Technol. 2011, 59, 227-231. [CrossRef]

38. Reddy, S.; Sharma, R.J. Effect of pre-harvest application of salicylic acid on the postharvest fruit quality of the Amrapali mango (Mangifera indica). Indian J. Agric. Sci. 2016, 86, 727-731. 